\title{
EFFECTS OF $\beta_{1}$-ADRENOCEPTOR AGONISM ON PLASMA RENIN ACTIVITY IN NORMAL MEN
}

\author{
J. STAESSEN ${ }^{1}$, A. CATTAERT ${ }^{1}$, A. DE SCHAEPDRYVER ${ }^{2}$, R. FAGARD ${ }^{1}$, \\ P. LIJNEN ${ }^{1}$, E. MOERMAN ${ }^{2}$ \& A. AMERY ${ }^{1}$ \\ 'Hypertension and Cardiovascular Rehabilitation Unit, Department of Pathophysiology, Katholieke Universiteit \\ van Leuven, Belgium, and 'Heymans Institute of Pharmacology, Ghent University Medical School, Rijksuniversiteit \\ van Ghent, Belgium
}

\begin{abstract}
The contribution of $\beta_{1}$-adrenoceptors to the regulation of plasma renin activity was investigated in nine healthy sodium-replete volunteers: seven subjects received a cumulative intravenous dose of 75 $\mu \mathrm{g} / \mathrm{kg}$ prenalterol, a predominant $\beta_{1}$-adrenoceptor agonist, and two subjects only vehiculum. In the seven actively treated subjects $\beta_{1}$-adrenoceptor agonism increased $(P<0.001)$ systolic intra-arterial pressure by an average of $16 \pm 4 \mathrm{~mm} \mathrm{Hg}$ and heart rate by $19 \pm 3$ beats min. These increases were significantly $(P<0.04)$ different from the changes observed in the two control subjects $(+3 \pm 4$ $\mathrm{mm} \mathrm{Hg}$ and $-1 \pm 4$ beats/min, respectively). Plasma renin activity, however, tended to decrease in both the actively $(-38 \%)$ and saline $(-28 \%)$ treated subjects. Predominant $\beta_{1}$-adrenoceptor agonism, powerful enough to increase systolic pressure and heart rate does not increase plasma renin activity in supine sodium-replete normal man.
\end{abstract}

Keywords plasma renin activity prenalterol $\beta_{1}$-adrenoceptors

\section{Introduction}

There is general agreement that stimulation of the sympathetic renal nerves promotes renin release (Peart, 1978). Presumably this effect is mediated by the liberation from the sympathetic nerve endings of small quantities of the neurotransmitter, noradrenaline, which in turn interacts with $\beta$-adrenoceptors located on the juxtaglomerular cells. The exact nature of the $\beta$-adrenoceptor involved, either $\beta_{1}$ or $\beta_{2}$ remains however a matter of controversy. Given the unknown nature of the juxtaglomerular $\beta$-adrenoceptor, the present study investigated whether predominant $\beta_{1}$-adrenoceptor agonism, using prenalterol as a pharmacological tool, affected plasma renin activity in healthy human subjects.

\section{Methods}

\section{Subjects}

Nine healthy men signed a written consent and participated in the study after the experimental procedures had been explained. Their age averaged $24.3 \pm$ 0.5 years (mean \pm s.e. mean); their height $179 \pm 2 \mathrm{~cm}$ and body weight $73.7 \pm 2.4 \mathrm{~kg}$. They remained on a liberal sodium intake. Their urinary sodium excretion averaged $146 \pm 14 \mathrm{mmol} / 24 \mathrm{~h}$.

\section{Experimental protocol}

The experiments were performed in an air conditioned laboratory where room temperature was stabilized at $18-22^{\circ} \mathrm{C}$ and humidity at $40-60 \%$. One week to three months before the actual experiments the subjects were familiarized with the laboratory conditions.

The subjects collected their $24 \mathrm{~h}$ urine on the 2 days immediately preceding the experiments. On the morning of these tests, the subjects came again to the laboratory where they were investigated always on the same day of the week. A small catheter (Vygon 115.09) was introduced into the brachial artery for continuous registration of intra-arterial pressure and for sampling of arterial blood. In addition, an intravenous line was placed in an antecubital vein and kept patent with saline $(\mathrm{NaCl}) 0.9 \%, 0.3 \mathrm{ml} / \mathrm{min}$. The subjects were then investigated during three consecutive experimental periods of $35 \mathrm{~min}$ each, while resting in the recumbent position. During the first baseline period no intervention took place. Prenalterol was dissolved in $20 \mathrm{ml}$ saline $0.9 \%$. Seven volunteers were administered intravenously 15 and $60 \mu \mathrm{g}$ prenalterol/ $\mathrm{kg}$ body weight, respectively at the start of the second and third experimental period, while two subjects received only vehiculum. 


\section{Haemodynamic variables}

Systolic and diastolic intra-arterial pressure were measured directly through the indwelling catheter in the brachial artery, using an electronic transducer (Elema Schönander EMT 34) and recorded continuously on a Mingograph 81 inkjet recorder. Mean arterial pressure was obtained by electrical damping. Heart rate was determined from the electrocardiogram which was continuously registered during the experiments. The haemodynamic measurements were averaged for the last $10 \mathrm{~min}$ of the control period and for $5 \mathrm{~min}$ periods beginning 5 and $30 \mathrm{~min}$ after the start of each injection. The average values thus obtained were employed for further statistical analysis.

\section{Biochemical variables}

At the end of the control period and 10 and $35 \mathrm{~min}$ after both bolus injections $10 \mathrm{ml}$ arterial blood was withdrawn for the determination of plasma renin activity (PRA) (Fyhrquist \& Puutula, 1978) and the concentration of renin substrate (PRS) (Gould et al., 1979), adrenaline (Da Prada \& Zürcher, 1976) and noradrenaline (Da Prada \& Zürcher, 1976). The interassay coefficients of variations for these measurements were $6.5,9.3,9.4$ and $7.4 \%$, respectively. Plasma samples were kept deep frozen at $-20^{\circ} \mathrm{c}$ until assayed.

Twenty-four hour urine collections were analysed for sodium and creatinine.

\section{Statistical analysis}

Two-way analysis of variance was used to evaluate in the seven actively treated subjects the effects of predominant $\boldsymbol{\beta}_{1}$-adrenoceptor-agonism on blood pressure, heart rate and plasma measurements. Student's $t$-test for unpaired data and two-tailed significance levels were used to compare the changes occurring after the prenalterol injections in the seven actively treated volunteers with those observed after saline in the two control subjects.

The distributions of plasma renin and plasma catecholamines were positively skew. A logarithmic transformation was therefore applied to normalize these distributions and stabilize variances before analysis of variance was performed. Dispersion of the data is given by the s.e. mean.

\section{Results}

\section{Blood pressure and heart rate}

After $\beta_{1}$-adrenoceptor stimulation systolic intraarterial pressure (Figure 1) increased by $16.2 \pm 4.2$
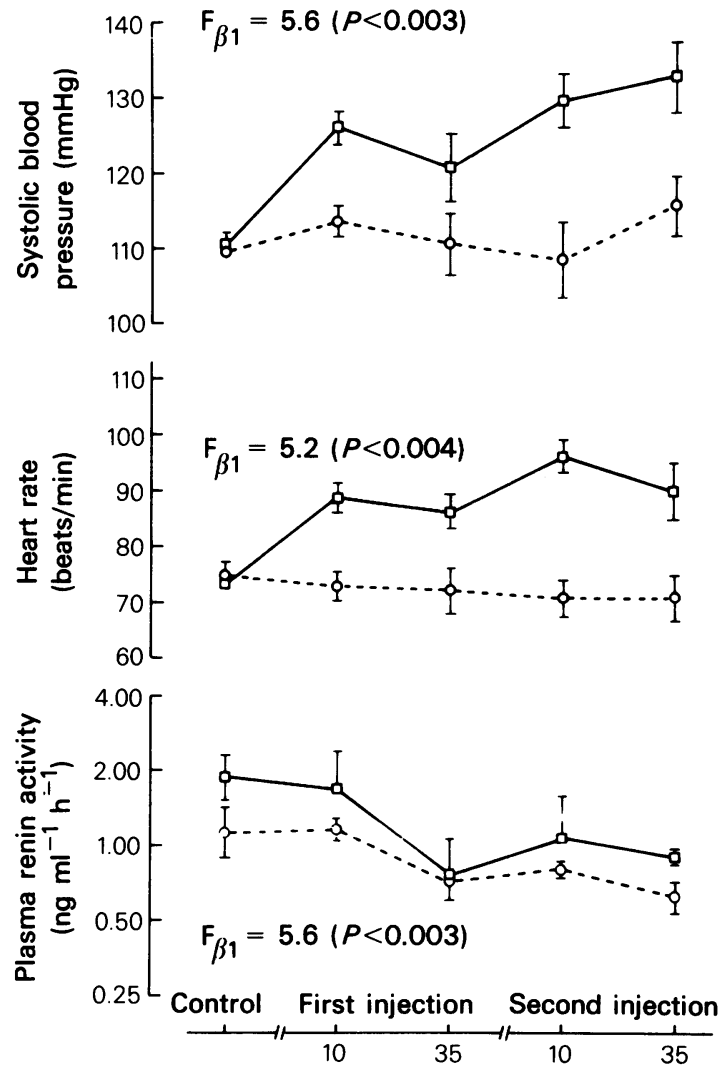

TIme after the start of the first and second injection ( $\mathrm{min}$ )

Figure 1 Intra-arterial systolic pressure, heart rate and plasma renin activity in seven subjects receiving two consecutive intravenous doses of prenalterol (15 and 60 $\mu \mathrm{g} / \mathrm{kg}$, respectively) ( $\square)$ and in two control subjects, receiving only vehiculum $(O)$. The $F$-values obtained by two-way analysis of variance refer to the effects of $\beta_{1^{-}}$adrenoceptor agonism. Values presented are means \pm s.e. mean.

$\mathrm{mm} \mathrm{Hg}(F=5.63, P<0.003)$; diastolic pressure (Table 1) by $5.9 \pm 1.2 \mathrm{~mm} \mathrm{Hg}(F=7.53 ; P<0.001)$; mean intra-arterial pressure (Table 1 ) by $8.0 \pm 1.2$ $\mathrm{mm} \mathrm{Hg}(F=8.67 ; P<0.001)$ and heart rate (Figure 1) by $19.3 \pm 3.0$ beats $/ \mathrm{min}(F=5.23 ; P<0.004)$. In the two control subjects only small changes in systolic pressure $(+3.0 \pm 4.2 \mathrm{~mm} \mathrm{Hg})$ and heart rate $(-1.1 \pm$ 3.8 beats $\mathrm{min})$ were observed after the injection of saline, whereas diastolic $(+6.9 \pm 1 \mathrm{~mm} \mathrm{Hg})$ and mean $(+4.7 \pm 1.3 \mathrm{~mm} \mathrm{Hg})$ intra-arterial pressure tended to increase. For systolic pressure $(P<0.04)$ and heart rate $(P<0.001)$ the changes observed after prenalterol in the seven actively treated volunteers were significantly different from those occurring after saline in the two control subjects. 
Table 1 Effects of predominant $\beta_{1}$-adrenoceptor stimulation on different variables

\begin{tabular}{lcccccc}
\hline & Baseline & \multicolumn{2}{c}{$\begin{array}{c}\text { After first injection of } \\
\text { prenalterol }(15 \mu \mathrm{kg})\end{array}$} & \multicolumn{2}{c}{$\begin{array}{c}\text { After second injection of } \\
\text { prenalterol }(60 \mu \mathrm{\mu g} / \mathrm{kg})\end{array}$} & $\mathrm{P}$ \\
$10 \mathrm{~min}$ & $35 \mathrm{~min}$ & $10 \mathrm{~min}$ & $35 \mathrm{~min}$ & \\
$\begin{array}{c}\text { Mean intra-arterial } \\
\text { pressure (mm Hg) }\end{array}$ & $67 \pm 1$ & $74 \pm 1$ & $75 \pm 2$ & $74 \pm 1$ & $77 \pm 2$ & $<0.001$ \\
$\begin{array}{c}\text { Diastolic intra-arterial } \\
\text { pressure (mm Hg) }\end{array}$ & $50 \pm 1$ & $55 \pm 1$ & $60 \pm 2$ & $53 \pm 1$ & $57 \pm 2$ & $<0.001$ \\
$\begin{array}{c}\text { Plasma renin substrate } \\
\quad(\mu \mathrm{g} / \mathrm{ml})\end{array}$ & $1.20 \pm 0.12$ & $1.20 \pm 0.12$ & $1.18 \pm 0.13$ & $1.14 \pm 0.09$ & $1.21 \pm 0.10$ & $\mathrm{NS}$ \\
$\begin{array}{c}\text { Plasma adrenaline } \\
(\mathrm{ng} / \mathrm{ml})^{*}\end{array}$ & $0.08 \pm 0.02$ & $0.07 \pm 0.04$ & $0.06 \pm 0.03$ & $0.08 \pm 0.05$ & $0.07 \pm 0.05$ & $\mathrm{NS}$ \\
$\begin{array}{c}\text { Plasma noradrenaline } \\
(\mathrm{ng} / \mathrm{ml})^{*}\end{array}$ & $0.43 \pm 0.04$ & $0.38 \pm 0.06$ & $0.36 \pm 0.03$ & $0.37 \pm 0.04$ & $0.34 \pm 0.03$ & $\mathrm{NS}$
\end{tabular}

Values presented are arithmetic means \pm standard error of the original data. The $P$-value, obtained by two-way analysis of variance refers to the effect of $\beta_{1}$-adrenoceptor agonism. Significance levels for items denoted by an asterisk were derived after normalizing the data by a logarithmic transformation. NS = not significant.

\section{Plasma measurements}

When the seven prenalterol treated subjects were followed while remaining recumbent, PRA (Figure 1) decreased from its baseline value by $38 \pm 1 \%(F=$ 5.64; $P<0.003$ ) while PRS (Table 1) and the plasma catecholamines (Table 1) did not change significantly $(F<1.82)$. In the two control subjects, PRA (Figure 1) tended to decrease after the administration of saline $(-28 \pm 1 \%)$ but the changes in PRS and in the plasma catecholamines were very small. The decrease in PRA was statistically not different $(t=0.63)$ between the seven actively treated and the two saline treated subjects.

\section{Discussion}

The results of the present study demonstrate that predominant $\beta_{1}$-adrenoceptor stimulation, powerful enough to provoke a marked rise in systolic pressure and heart rate was unable to produce any increase in the plasma renin activity of supine sodium-replete men. If anything, rather a decrease than a rise in plasma renin activity was observed in both the actively treated and control subjects. This decrease might be explained by the prolonged recumbency during the experiments.

Several mechanisms may be invoked to explain why the plasma renin activity in normal subjects remained unresponsive to predominant $\beta_{1}$-adrenoceptor stimulation. First, it is conceivable that the systolic pressor effect brought about by selective $\beta_{1}$ adrenoceptor agonism activated baroreceptors located in the renal efferent arterioli, in the carotid sinus or in the aortic arch. Arterial baroreceptor reflexes might counterbalance the direct juxtaglomerular action of predominant $\boldsymbol{\beta}_{1}$-adrenoceptor agonism, resulting in no net change in plasma renin activity. However, $\beta_{1}$-adrenoceptor agonism did not result in significant changes in the plasma levels of adrenaline and noradrenaline. To the extent that circulating catecholamines in resting subjects reflect the activity of the adrenergic system (Bravo \& Tarazi, 1982), the latter observation could indicate that the adrenergic outflow from the central nervous system was not reduced during prenalterol infusion. Furthermore, Mancia et al. (1981) have presented evidence suggesting that carotid baroreflexes do not have a major impact on renin secretion, but the neck chamber used by these investigators does not permit any conclusion on the possible influence on plasma renin of receptors located in the renal efferent arterioli and in the aorta.

From the present work it cannot be excluded that the effects of $\beta_{1}$-adrenoceptor agonism on renin release were antagonized by an increased sodium concentration or load at the macula densa (Peart, 1978). However, a previous study (Meurer et al., 1980 ) in healthy volunteers demonstrated that an intravenous infusion of prenalterol did not produce significant alterations in renal blood flow, glomerular filtration, filtration fraction and sodium clearance.

Finally, the possibility should be considered that the secretion of renin is mainly dependent upon $\beta_{2^{-}}$ adrenoceptors or alternatively upon a particular type of $\beta$-adrenoceptor, which does not fit the presently available means of pharmacological identification. By contrast to prenalterol, non-selective $\beta$-adrenoceptor agonists, such as isoprenaline (Seymour et al., 1981) and predominant $\boldsymbol{\beta}_{2}$-adrenoceptor agonistic agents like fenoterol (Meurer et al., 1976, 1980) have been reported to increase plasma renin in vivo. On the other hand predominant $\beta_{1}$-adrenoceptor blocking 
agents such as atenolol (Amery et al., 1976) and metoprolol (Lijnen et al., 1979) are able to inhibit the renin secretion. However, selective $\beta_{2}$-adrenoceptor blockers, have been shown to antagonize the secretion of renin provoked by isoprenaline and to be more powerful than non-selective and selective $\beta_{1}$-adrenoceptor blockers in these experimental models (Weber et al., 1974; Imbs et al., 1977). The latter results together with the findings of the present study could indicate that $\beta_{1}$-adrenoceptors are either not at all or only to a minor extent involved in the modulation of the secretion of renin.

\section{References}

AMERY, A., BILLIET, L., BOEL, A., FAGARD, R., REYBROUCK, T. \& WILLEMS, J. (1976). Mechanism of hypotensive effect during beta-adrenergic blockade in hypertensive patients: hemodynamic and renin response to a new cardio-selective agent; Tenormin or ICI 66,082 . Am. Heart J., 91, 634-642.

BRAVO, E.L. \& TARAZI, R.C. (1982). Plasma catecholamines in clinical investigation: a useful index or a meaningless number? J. lab. clin. Med., 100, 155-159.

DA PRADA, M. \& ZÜRCHER, G. (1976). Simultaneous determination of plasma and tissue adrenaline, noradrenaline and dopamine within the fentomole range. Life Sci., 19, 1161-1174.

FYHRQUIST, F. \& PUUTULA, L. (1978). Faster radioimmunoassay of angiotensin I at $37^{\circ} \mathrm{C}$. Clin. Chem., 24, 115-118.

GOULD, A.B., GOODMAN, S., DE WOLF, R., ONESTI, G. \& SWARTZ, C. (1979). Measurement of renin and substrate concentration in human plasma. Analyt. Biochem., 94, 125-139.

IMBS, J.L., MIESCH, F., SCHWARTZ, J., VELLY, J., LECLERC, G., MANN, A. \& WERMUTH, C.G. (1977). A potent new $\beta_{2}$-adrenoceptor blocking agent. $B r$. J. Pharmac., 60, 357-362.

LIJNEN, P.J., AMERY, A.K., FAGARD, R.H., REYBROUCK, T.M., MOERMAN, E.J. \& DE SCHAEPDRYVER, A.F. (1979). The effects of $\beta$-adrenoceptor blockade on renin, angiotensin, aldosterone and catecholamines at rest and during exercise. Br. J. clin. Pharmac., 7, 175-181.
The authors gratefully acknowledge the expert technical and secretarial assistance provided by Mrs V. Mariën, Mrs Y. Toremans, Mr J. Delsupehe, Mr R. Grauwels and Mr J. Romont.

Astra-Nobelpharma N.V., Belgium, kindly supplied prenalterol.

Research in our laboratory is partially supported by grants of the Belgian Research Institute 'Nationaal Fonds voor Wetenschappelijk Onderzoek'.

MANCIA, G., FERRARI, A., LEONETTI, G., GREGORINI, L., TERZOLI, L., PARATI, G., BIANCHINI, C. \& ZANCHETTI, A. (1981). Carotid sinus reflex control of renin release in hypertensive subjects with high renin secretion. Clin. Sci., 61, 505-509.

MEURER, K.A., MAXRATH, L., HELBER, A. \& KAUFMANN, W. (1976). Uber die Beteiligung $\beta_{1}$ - und $\beta_{2}$ adrenerger Rezeptoren an der Reninfreisetzung. Verh. Dtsch. Ges. Inn. Med., 82, 1296-1299.

MEURER, K.A., LANG, R., HOMBACH, V. \& HELBER, A. (1980). Effects of a $\beta_{1}$-selective adrenergic agonist in normal human volunteers. Klin. Wochenschr., 58, 425-427.

PEART, W.S. (1978). Renin 1978. Johns Hopkins med. J., 143, 193-206.

SEYMOUR, A.A., DAVIS, J.O., ECHTENKAMP, S.F., DIETZ, J.R. \& FREEMAN, R.H. (1981). Adrenergically induced renin release in conscious indomethacin-treated dogs and rats. Am. J. Physiol., 240, F515-F521.

WEBER, M.A., STOKES, G.S. \& GAIN, J.M. (1974). Comparison of the effects on renin release of beta-adrenergic antagonists with different properties. J. clin. Invest., 54, 1413-1419.

(Received April 18, 1983, accepted June 27, 1983) 